\title{
Upaya Peningkatan Ekonomi Masyarakat Melalui Pengembangan Usaha Agribisnis Pedesaan (PUAP) di Desa Hanopan Kecamatan Arse Kabupaten Tapanuli Selatan
}

\author{
Iwan Sodogoron Harahap \\ Sekolah Tinggi IImu Ekonomi (STIE) Kampus Padangsidimpuan \\ Email: iwansodogoron@gmail.com
}

\begin{abstract}
Abstrak
Permasalahan kemiskinan di pedesaan merupakan salah satu masalah pokok pedesaan yang harus segera diselesaikan dan menjadi prioritas utama dalam pelaksanaan pembangunan kesejahteraan sosial. Untuk mengatasi permasalahan tersebut pemerintah menetapkan Program Pengembangan Usaha Agribisnis Perdesaaan (PUAP).

Tujuan penelitian ini adalah untuk mengetahui upaya peningkatan ekonomi masyarakat di Desa Hanopan Kecamatan Arse Kabupaten Tapanuli Selatan, untuk mengetahui dampak apa saja yang timbul dalam upaya peningkatan ekonomi masyarakat melalui Program Pengembangan Usaha Agribisnis Perdesaan di Desa Hanopan Kecamatan Arse Kabupaten Tapanuli Selatan.

Metode yang digunakan dalam penelitian ini adalah metode deskriptif dengan analisis deskriptif kualitatif yaitu suatu proses dan cara menganalisis, menafsirkan, mengklasifikasikan data sehingga dapat memberikan gambaran umum yang jelas. Sedangkan teknik pengumpulan data dilakukan dengan observasi dan wawancara dengan pihak yang bersangkutan.

Berdasarkan hasil penelitian yang telah dilakukan, upaya peningkatan ekonomi masyarakat di Desa Hanopan Kecamatan Arse Kabupaten Tapanuli Selatan meningkatkan pola pertanian dari yang tradisional menjadi lebih modern. Hal ini dilihat dari yang biasanya dalam setahun satu kali panen, sekarang sudah dua kali, karena sudah tersedia bibit, pupuk, dan pestisida dari PPL, melalui PUAP di Desa Hanopan sudah berhasil dilaksanakan, mulai dari pembibitan, cara tanam, serta pola bertani yang sudah lebih maju. Kehadiran program PUAP telah dapat memberikan dampak positif bagi kesejahteraan petani karena program ini pada dasarnya memberikan bantuan penguatan modal bagi petani. Bantuan modal usaha yang diharapkan dapat meningkatkan pendapatan usaha yang mendukung pendapatan rumah tangga petani sehingga meningkatkan kesejahteraan keluarga.
\end{abstract}

Kata kunci: Agribisnis, Desa, Ekonomi, Upaya

Abstract
The problem of rural poverty is one of the main rural issues that must be
resolved and become the main priority in the implementation of social welfare
development. To overcome these problems, the government established the
Business Development Program of Agribusiness Perdesaaan.
The purpose of this research is to know the effort of economic improvement of
society in Hanopan Village, Arse Subdistrict, South Tapanuli Regency, to know
the impact of what arises in the effort of improving the economy of society
through Rural Agribusiness Development Program in Hanopan Village, Arse
District, South Tapanuli Regency.
The method used in this research is descriptive method with qualitative
descriptive analysis is a process and how to analyze, interpret, classify data so
as to give a clear general picture. While the technique of data collection is done
by observation and interview with the parties concerned.
Based on the results of research that has been done, efforts to increase the
economic community in Hanopan Village District Arse South Tapanuli improve
farming patterns from the traditional to be more modern. This is seen from the
usual one-year harvest, now twice, because already available seedlings,


fertilizers, and pesticides from the PPL, through PUAP in Hanopan Village has been successfully implemented, ranging from seeding, planting methods, and farming patterns that have been more advanced. The presence of the PUAP program can have a positive impact on the welfare of farmers because the program basically provides assistance to strengthen the capital for farmers. Business capital aid is expected to increase business income that support the household income of farmers so as to improve family welfare.

Keywords: Agribusiness, Village, Economy, Effort

\section{PENDAHULUAN}

Permasalahan kemiskinan di pedesaan merupakan salah satu masalah pokok pedesaan yang harus segera diselesaikan dan menjadi prioritas utama dalam pelaksanaan pembangunan kesejahteraan sosial. Oleh karena itu pembangunan ekonomi nasional berbasis pertanian dan perdesaan secara langsung akan berdampak pada pengurangan penduduk miskin.

Permasalahan mendasar yang dihadapi petani adalah kurangnya akses pada sumber permodalan, pasar dan teknologi, serta organisasi petani yang masih lemah. Untuk mengatasi permasalahan tersebut pemerintah menetapkan Program Pengembangan Usaha Agribisnis Perdesaaan (PUAP) yang mulai dilaksanakan pada tahun 2008 dimana tujuan dari program ini adalah untuk mempercepat tumbuh dan berkembangnya usaha agribisnis dengan sasaran mengurangi kemiskinan dan pengangguran di perdesaan.

Pengembangan Usaha Agribisnis Perdesaaan (PUAP) merupakan salah satu program yang dikembangkan oleh Departemen Pertanian yang dilaksanakan secara terintegrasi dengan Program Nasional Pemberdayaan Masyarakat Mandiri (PNPM-M). PUAP merupakan bentuk fasilitas modal usaha untuk petani, baik petani pemilik, petani penggarap, buruh tani, maupun rumah tangga miskin di perdesaan. Salah satu tujuan dari PUAP adalah untuk mengurangi kemiskinan dan pengangguran dengan menggerakkan kegiatan agribisnis sesuai potensi wilayah. Sedangkan sasaran PUAP salah satunya adalah untuk meningkatkan kesejahteraan rumah tangga tani miskin, petani skala kecil, dan buruh tani.
Dalam usaha tani membutuhkan biaya yang cukup besar. Keterbatasan dan kesulitan petani dalam memperoleh modal usaha tani, mengakibatkan usaha tani mereka terbengkalai. Rendahnya pengetahuan petani membuat mereka kurang paham bagaimana cara memperoleh kredit atau pinjaman sehingga menyebabkan lemahnya akses petani terhadap lembaga keuangan yang ada. Persoalan ini sering terjadi di kalangan petani dalam menanggapi program pemerintah lainnya, anggota sering mengganggap bahwa dana program pemerintah adalah pinjaman Cuma-cuma yang tidak harus dikembalikan kepada lembaga keuangan yang mengelola.

Masalah kemiskinan di pedesaan selalu berhubungan dengan petani. Hal ini dikarenakan mayoritas pekerjaan masyarakat desa adalah pertanian. Munculnya paradigma bahwa petani adalah golongan ekonomi ke bawah inilah yang menjadikan pertanian semakin kehilangan peminatnya. Padahal pertanian merupakan tulang punggung ekonomi Negara. Pertanian yang maju, akan mengurangi ketergantungan dengan negara lain di sektor pangan, sehingga efek krisis moneter global bisa diredam.

Ada beberapa aspek yang menyebabkan program penanggulangan kemiskinan yang selama ini berjalan tidak efektif, yaitu :

a. Kemampuan pemerintah pusat dan daerah dalam mengimplementasikan setiap program masih terbatas;

b. Masih terbatasnya database kemiskinan sehingga sulit menjadikan program tepat sasaran dan pengawasan program masih lemah;

c. Masih maraknya praktek-praktek korupsi di Indonesia 
d. Kurangnya partisipasi masyarakat dalam upaya penanggulangan kemiskinan. (Sumaryadi, 2005:54)

Program Pengembangan Usaha Agribisnis Perdesaan (PUAP) merupakan program nasional dalam rangka pengentasan kemiskinan pada sektor pertanian. Program ini berupa pemberian dana bantuan penguatan modal kepada petani. Petani diharapkan memanfaatkan dana tersebut untuk mengembangkan agribisnis mereka untuk meningkatkan pendapatan petani sehingga petani keluar dari kemiskinan.

Namun kenyataannya Program Pengembangan Usaha Agribisnis Perdesaan (PUAP) belum sepenuhnya tercapai dengan baik. Hal ini dibuktikan melalui hasil survei yang dilakukan penulis di Desa Hanopan sebagian masyarakat mengalami kemacetan dalam pengembalian dana Program Pengembangan Usaha Agribisnis Perdesaan (PUAP), hal ini disebabkan oleh beberapa hal antara lain: usaha yang dilaksanakan mengalami kegagalan, menganggap dana tersebut adalah hibah atau bantuan lepas, dipakai untuk keperluan lain yang lebih mendesak dan lain sebagainya.

Pengembalian pinjaman ini diharapkan $100 \%$ karena keberhasilan program PUAP ini sangat ditentukan oleh tersedianya dana pendukung. Hal ini harus dipahami oleh seluruh anggota yang meminjam, bahwa tanpa dukungan dana maka program PUAP tidak akan berjalan sebagaimana mestinya.

Dana Pengembangan Usaha Agribisnis Perdesaan (PUAP) yang diterima Desa Hanopan tersebut sebesar Rp 39 juta untuk mengembangkan agribisnis perdesaan melalui Kelompok Wanita Tani Bina Maju oleh ketua Rahmawati. Dana diberikan kepada masyarakat agar:

1. Mengurangi kemiskinan dan pengangguran melalui penumbuhan dan pengembangan kegiatan usaha agribisnis di pedesaan sesuai dengan potensi wilayah;

2. Meningkatkan kemampuan pelaku usaha agribisnis,

3. Memberdayakan kelembagaan petani dan ekonomi perdesaan untuk pengembangan kegiatan usaha agribisnis.

4. Meningkatkan fungsi kelembagaan ekonomi petani menjadi jejaring atau mitra lembaga keuangan dalam rangka akses ke permodalan.

Desa Hanopan Kecamatan Arse merupakan salah satu sektor pertanian yang sudah tertata cukup baik. Keadaan alam di Desa Hanopan secara umum juga cocok untuk pertanian. Kredit ringan untuk petani dirasa memang sangat dibutuhkan. Hal ini dikarenakan harga faktor produksi seperti pupuk yang semakin meningkat, sehingga banyak petani yang kekurangan modal untuk membeli pupuk atau sarana yang lain.

Pertumbuhan ekonomi, secara umum di Desa Hanopan mengalami kenaikan pada tahun-tahun terakhir ini. Tetapi walaupun pertumbuhan ekonomi semakin meningkat, permasalahan kemiskinan masih menjadi masalah yang belum terpecahkan. Kemiskinan lebih banyak ditemui di desa dibandingkan di kota, dikarenakan lapangan pekerjaan di pedesaan lebih sedikit dibanding di kota.

Dana PUAP untuk program penanggulangan kemiskinan meningkat setiap tahunnya. Kian besarnya volume bantuan dana PUAP setiap tahun ternyata berbanding terbalik dengan penurunan warga miskin. Hal ini menunjukkan program penanggulangan kemiskinan belum maksimal, sehingga perlu dievaluasi sejauh mana dampak pelaksanaan program PUAP tersebut bisa mengurangi angka kemiskinan.

Berdasarkan latar belakang masalah tersebut, maka penulis tertarik untuk melakukan penelitian dengan mengambil judul "Upaya Peningkatan Ekonomi Masyarakat Melalui Pengembangan Usaha Agribisnis Pedesaan (Puap) di Desa Hanopan Kecamatan Arse Kabupaten Tapanuli Selatan".

\section{Rumusan Masalah}

Berdasarkan latar belakang masalah yang dikemukakan di atas, maka penulis merumuskan permasalahan penelitian ini yaitu; 
1. Bagaimana upaya peningkatan ekonomi masyarakat di Desa Hanopan Kecamatan Arse Kabupaten Tapanuli Selatan?

2. Dampak apa saja yang timbul dalam upaya peningkatan ekonomi masyarakat melalui Program Pengembangan Usaha Agribisnis Perdesaan (PUAP) di Desa Hanopan Kecamatan Arse Kabupaten Tapanuli Selatan?

\section{Tujuan Penelitian}

adalah;

Adapun tujuan dari penelitian ini

1. Untuk mengetahui upaya peningkatan ekonomi masyarakat di Desa Hanopan Kecamatan Arse Kabupaten Tapanuli Selatan.

2. Untuk mengetahui dampak apa saja yang timbul dalam upaya peningkatan ekonomi masyarakat melalui Program Pengembangan Usaha Agribisnis Perdesaan (PUAP) di Desa Hanopan Kecamatan Arse Kabupaten Tapanuli Selatan.

\section{Manfaat Penelitian}

Adapun yang menjadi manfaat penelitian ini adalah;

1. Untuk menambah wawasan ilmu pengetahuan bagi penulis mengetahui Program Pengembangan Usaha Agribisnis Perdesaan (PUAP) di Desa Hanopan Kecamatan Arse Kabupaten Tapanuli Selatan.

2. Penelitian ini diharapkan dapat memberi masukan dalam pemikiran dan pengetahuan bagi pihak-pihak yang berkepentingan, khususnya tentang Pengembangan Usaha Agribisnis Perdesaan (PUAP).

\section{METODE}

Dalam penelitian ini penulis menggunakan bentuk penelitian dengan metode deskriptif dengan analisis kualitatif. Sugiyono menyatakan bahwa Metode Penelitian Kualitatif adalah metode penelitian yang berlandaskan pada filsafat postpositivisme, digunakan untuk meneliti pada kondisi obyek yang alamiah, (sebagai lawannya adalah eksperimen) dimana peneliti adalah sebagai instrumen kunci, tehnik pengumpulan data dilakukan secara triangulasi (gabungan), analisis data bersifat induktif/ kualitatif dan hasil penelian kualitatif lebih menekankan makna dari pada generalisasi. (2010:9)

Selanjutnya Suharsimi Arikunto menyatakan bahwa "penelitian deskriptif adalah penelitian yang dimaksud untuk menyelidiki keadaan, kondisi, atau hal-hal lain yang sudah disebutkan, yang hasilnya dipaparkan dalam bentuk laporan penelitian"(2010:3).

\section{Informan Penelitian}

Informan Penelitian yang dibutuhkan adalah seseorang yang mempunyai pengetahuan tentang objek penelitian, yang lajimnya berkaitan dengan sifat dan keadaan kelembagaan termasuk pranata masyarakat. Informasi yang akan di peroleh dari informan penelitian bukan bersifat pribadi, melainkan informasi kelembagaan.

Dalam penelitian ini ditentukan melalui mekanisme disengaja (purposive), yaitu orang yang di anggap ahli atau mengetahui tentang masalah yang sedang di teliti. Dalam penelitian ini informannya adalah masyarakat di Desa Hanopan Kecamatan Arse Kabupaten Tapanuli Selatan

\section{Defenisi Konsep}

Konsep merupakan suatu abstraksi yang di bentuk untuk menggeneralis asikan hal-hal yang bersifat khusus secara abstrak dari suatu fenomena sosial.

Dalam penelitian ini ada beberapa konsep yang di angkat, yaitu:

\section{Pengertian Upaya}

Upaya adalah tindakan yang dilakukan seseorang, untuk mencapai apa yang diinginkan atau merupakan sebuah strategi. Upaya meurut Poerwodarminta adalah usaha (syarat) untuk menyampaikan suatu maksud, akal, ikhtiar (2005:1132). Upaya adalah aspek yang dinamis dalam kedudukan (status) terhadap sesuatu. Apabila seseorang melakukan hak dan kewajibannya sesuai dengan kedudukannya, maka ia menjalankan suatu upaya ( Ngalim Purwanto, 2007:62). Upaya dijelaskan sebagai usaha (syarat) suatu cara, juga dapat dimaksud sebagai suatu 
kegiatan yang dilakukan secara sistematis, terencana dan terarah untuk menjaga sesuatu hal agar tidak meluas atau timbul.

\section{Peningkatan.}

Peningkatan berasal dari kata tingkat, yang berarti lapis atau lapisan dari sesuatu yang kemudian membentuk susunan. Tingkat juga dapat berarti pangkat, taraf, dan kelas. Sedangkan peningkatan berarti kemajuan. Secara umum, peningkatan merupakan upaya untuk menambah derajat, tingkat, dan kualitas maupun kuantitas. "Peningkatan juga dapat berarti penambahan keterampilan dan kemampuan agar menjadi lebih baik. Selain itu, peningkatan juga berarti pencapaian dalam proses, ukuran, sifat, hubungan dan sebagainya" (Adi S, 2007:46).

\section{Pengertian Masyarakat}

Masyarakat adalah sejumlah manusia yang merupakan satu kesatuan golongan yang berhubungan tetap dan mempunyai kepentingan yang sama. Dalam pengertian masyarakat banyak pendapat dari para ahli yang berbeda dalam mengartikan masyarakat itu sendiri. Munandar Soelaman mengartikan masyarakat sebagai "adanya interaksi atau saling bergaul karena ada bentuk-bentuk aturan hidup yang bukan disebabkan oleh manusia sebagai perseorangan melainkan oleh unsur-unsur kekuatan lain dalam lingkungan sosial yang merupakan suatu kesatuan".

Menurut Soerjono Soekanto, "Masyakarat adalah orang-orang yang hidup bersama yang menghasilkan suatu kebudayaan"(1990:187). Dengan demikian, tak ada masyarakat yang tidak mempunyai kebudayaan dan sebaliknya tak ada kebudayaan tanpa masyarakat sebagai wadah dan pendukungnya.

Menurut M. Cholil Mansyur masyarakat di defenisikan sebagai "golongan besar atau kecil terdiri atas beberapa manusia dengan atau karena sendirinya bertalian secara golongan, masyarakat itu sendiri merupakan suatu kesatuan yang selalu berubah yang hidup karena proses mayarakat seperti tersebut diatas yang menyebabkan perubahan"
(1989:87), sehingga dapat disimpulkan bahwa masyarakat merupakan orang-orang yang hidup bersama atau golongan besar atau kecil dari beberapa manusia yang melakukan interaksi dan saling bergaul dalam lingkungan sosial yang berupa satu kesatuan, hidup secara mandiri, bebas dan menghasilkan suatu kebudayaan.

\section{Pengertian Ekonomi}

Ekonomi adalah ilmu tentang perilaku dan tindakan manusia untuk memenuhi kebutuhan hidupnya yang banyak, bervariasi dan berkembang dengan sumber daya yang ada melalui perubahan-perubahan kegiatan produksi, konsumsi dan distribusi.

Suherman Rosyidi menjelaskan : "Bahwa istilah ekonomi itu berasal dari bahasa yunani, yaitu Oikonomia. Kata tersebut merupakan turunan dari dua kata, yakni oikos dan nomos. Oikos berarti rumah tangga, sedangkan nomos berarti mengatur. Jadi arti asli oikonomia adalah mengatur rumah tangga" (2004:20). Lebih lanjut Muammar mengatakan bahwa kata "ekonomi" berasal dari bahasa Yunani Oikos dan nomos, oikos berarti rumah tangga dan nomos berarti aturan, kaidah atau pengelolaan. Dengan demikian membicarakan ekonomi berarti membicarakan aturan, kaidah, dan cara mengelola suatu rumah tangga manusia"( 2006:1).

Selanjutnya menurut M. Zainal Abidin istilah "ekonomi" berasal dari bahasa Yunani Oikos yang berarti keluarga, rumah tangga dan nomos atau peraturan,aturan, hukum, dan secara garis besar diartikan sebagai aturan rumah tangga "atau"manajemen rumah tangga" (2006:1)

Berdasarkan uraian diatas, arti asli tadi berkembang menjadi arti baru, sejalan dengan perkembangan ekonomi menjadi suatu ilmu. Kini sebagai ilmu ekonomi berarti pengetahuan yang tersusun menurut cara yang beraturan dalam rangka mengatur rumah tangga. Rumah tangga disini bukanlah arti sempit, melainkan menunjuk pada suatu kelompok sosial, yang dapat dianggap sebagai rumah tangga kelompok sosial ini dapat berwujud perusahaan, kota, bahkan negara. 
Paul Anthony Samuelson mengatakan bahwa :

1. IImu ekonomi adalah studi mengenai bagaimana orang menjatuhkan pilihan yang tepat untuk memanfaatkan sumber-sumber produktif (tanah, tenaga kerja, barang-barang modal semisal mesin, dan pengetahuan teknik) yang langka dan terbatas jumlahnya untuk menghasilkan berbagai barang serta mendistribusikannya kepada berbagai anggota masyarakat untuk mereka pakai atau konsumsi.

2. IImu ekonomi adalah suatu studi tentang cara-cara memperbaiki masyarakat (Suherman Rosyidi, 2004:24).

Sebagaimana dalam hal cara manusia dalam memenuhi kebutuhannya yang tidak terbatas tersebut, maka dengan menggunakan sumber daya (resources) manusia dapat mengusahakannya untuk memenuhi kebutuhan hidupnya.

Dengan mempelajari ekonomi manusia atau masyarakat dapat memilih dan berusaha untuk menggunakan sumber daya produksi yang terbatas yang memiliki penggunaan alternatif untuk memproduksi komoditas dan mendistribusikannya kekelompok yang lain dengan tujuan untuk mencapai kemakmuran.

Dari uraian di atas dapat disimpulkan bahwa ekonomi adalah adanya perubahan pengetahuannya, pemahamannya, sikap dan tingkah lakunya, keterampilannya, yang dimiliki siswa setelah menyelesaikan pengalaman belajarnya pada bidang studi ekonomi sesuai dengan tujuan yang telah dirumuskan.

\section{Pengertian Desa}

Desa atau kota merupakan suatu hasil perwujudan geografis yang ditimbulkan oleh unsur-unsur fisografis, sosial, ekonomi, politk dan kultural yang terdapat pada suatu daerah serta memiliki hubungan dan pengaruh timbal balik dengan daeah lain.

Munandar Soelaman mengartikan sebagai "Desa adalah perwujudan atau kesatuan geografi, sosial, ekonomi, politik, serta kultural yang terdapat di suatu daerah dalam hubungan dan pengaruhnya secara timbal balik dengan daerah lain" (2000:122). Menurut UU No. 6 Tahun 2014, "Desa adalah kesatuan masyarakat hukum yang memiliki batas wilayah yang berwenang untuk mengatur dan mengurus urusan pemerintahan, kepentingan masyarakat setempat berdasarkan prakarsa masyarakat, hak asal usul, dan/atau hak tradisional yang diakui dan dihormati dalam sistem pemerintahan Negara Kesatuan Republik Indonesia".

Menurut Soerjono Soekanto, "Desa adalah kesatuan wilayah yang dihuni oleh sejulah keluarga yang mempunyai sistem pemerintahan sendiri (dikepalai oleh seorang Kepala Desa) atau desa merupakan kelompok rumah di luar kota yang merupakan kesatuan". Dengan demikian, desa adalah tempat sebagian besar penduduk yang bermata pencarian di bidang pertanian dan menghasilkan bahan makanan.

Menurut M. Cholil Mansyur di defenisikan sebagai "Desa adalah suatu wilayah yang mempunyai tingkat kepadatan rendah yang dihuni oleh penduduk dengan interaksi sosial yang bersifat homogen, bermatapencaharian dibidang agraris serta mampu berinteraksi dengan wilayah lain di sekitarnya".

Dapat disimpulkan bahwa desa adalah salah satu bentuk kuno dari kehidupan bersama sebanyak beberapa ribu orang, hampir semuanya saling mengenal; kebanyakan yang termasuk didalamnya hidup dari pertanian, perikanan, dan usaha-usaha yang dapat dipengaruhi oleh hukum dan kehendak alam lainnya; dan dalam tempat tinggal itu terdapat banyak ikatan-ikatan keluarga yang rapat, ketaatan, dan kaidah-kaidah sosial.

\section{Pelaksanaan Pengembangan Usaha Agribisnis Pedesaan (PUAP)}

Pengembangan Usaha Agribisnis Pedesaan (PUAP) merupakan salah satu kegiatan dari Program Nasional Pemberdayaan Masyarakat Mandiri (PNPM-M) yang dilaksanakan oleh Departemen Pertanian, bertujuan untuk mempercepat tumbuh dan berkembangnya usaha agribisnis dengan sasaran mengurangi kemiskinan dan pengangguran di pedesaan. "Pelaksanaan PUAP, 
dirancang dan dilaksanakan oleh masyarakat secara partisifatif dengan membentuk kelompok tani, terintegrasi dengan kegiatan yang telah ada, ataupun yang dilakukan baik dilingkup Departemen Pertanian maupun Non Departemen Pertanian dan Pemerintah Daerah". Pembinaan kelompok tani pada penerapan sistem agribisnis diarahkan untuk meningkatkan peranan petani dan anggota masyarakat lainya dalam menumbuhkembangkan kerja sama antar petani dan pihak pemangku kepentingan. Dengan pembinaan kelompok tani diharapkan dapat menggali potensi dalam memecahkan masalah usaha pertanian secara efektif dan memudahkan dalam mengakses informasi pasar, teknologi dan sumberdaya lainya.

Pengembangan usaha agribisnis di pedesaan yang selanjutnya disebut dengan PUAP adalah bagian dari pelaksanaan program PNPM-Mandiri melalui bantuan modal usaha dalam menumbuhkembangkan usaha agribisnis sesuai dengan potensi pertanian desa sasaran. "Dalam rangka pelaksanan PUAP di Departemen Pertanian, maka Menteri Pertanian telah membentuk Tim Pengembangan Usaha Agribisnis Pedesaan dengan surat kepetusan Menteri Pertanian Nomor: 545/Kpts/OT.160/9/2007 dan Peraturan Menteri Pertanian (PERMENTAN) Nomor: 16/Permetaan/OT.140/2/2008, pada tanggal 11 Februari 2008 tentang Pedoman Umum PUAP". Guna mengetahui perkembangan pelaksanaan, penyaluran, dan pemanfaatan dana BLM-PUAP diperlukan monitoring, evaluasi, dan pelaporan secara sistematik, berjenjang, terukur, transparan, dan dapat dipertanggung jawabkan.

Setiap kegiatan memerlukan penilaian / evaluasi dimana evaluasi adalah kegiatan untuk menilai efisiensi dan efektifitas suatu kegiatan dengan menggunakan indikator-indikator tujuan yang telah ditetapkan. Evaluasi ini dilakukan secara sistematik dan obyektif serta terdiri dari evaluasi sebelum kegiatan dimulai, saat kegiatan berlangsung, dan sesudah kegiatan selesai.

\section{Teknik Analisis Data}

Dalam suatu penelitian ini sangat diperlukan suatu analisis data yang berguna untuk memberikan jawaban terhadap permasalahan yang diteliti. Data yang telah dikumpulkan kemudian dianalisis dengan cara menggambarkan dan mengkaji data kepustakaan dan data lapangan secara deduktif kemudian data tersebut dituangkan dalam bentuk narasi sehingga akan memudahkan penulis dalam menganalisa datanya.

\section{HASIL DAN PEMBAHASAN}

Desa Hanopan adalah salah satu Desa yang berada di kecamatan Arse. Penduduk Desa Hanopan berjumlah 906 jiwa yang terdiri dari 459 orang laki-laki dan 447 orang perempuan. Desa Hanopan termasuk daerah pedalaman karena daerahnya jauh dari pusat kota Padangsidimpuan yang berjarak sekitar 66 KM. Hanopan terletak di bagian selatan dari Provinsi Sumatera Utara, sebuah desa kecil yang mayoritas penduduknya adalah petani. Matahari selalu terlambat terbit di desa kecil itu, karena cahayanya terhalang punggung Gunung yang memiliki ketinggian 4.500 meter.

Pada pagi hari, sebelum matahari muncul, kabut tebal merangkak turun dari lereng-lereng gunung itu, ditiup oleh angin yang berembus dari arah Barat. Dari puncak gunung, menatap ke sebelah Barat, akan tampak bentangan hutan kawasan yang menghijau sejauh mata memandang sampai menghilang di pesisir Barat.

\section{Program Umum Pengembangan Usaha Agribisnis Pedesaan (PUAP)}

Program Pengembangan Usaha Agribisnis Pedesaan (PUAP) di Desa Hanopan telah mampu mengatasi kesulitan terhadap akses sumber permodalan namun masih banyak kekurangan dalam pelaksanaan di lapangan seperti:
a) Untuk menggulirkan dana PUAP sehingga setelah dana masuk rekening dibutuhkan waktu lama untuk bisa menggulirkan kepada petani.
b) Kurangnya pembinaan dari Penyuluh Pendamping dan Dinas Pertanian.
c) Kurangnya pelatihan yang diberikan kepada pengelola UKM (Usaha Kecil 
dan Menengah) sehingga pengelolaa UKM (Usaha Kecil dan Menengah) kurang bagus.

d) Masih tingginya tingkat kemacetan yang berpengaruh kepada belum tergulirkannya dana PUAP ke anggota karena masih berupa piutang pada anggota yang belum membayar angsuran pinjamannya.

Program PUAP telah berperan dalam pemberdayaan petani di Desa Hanopan yang ditandai dengan adanya peningkatan pendapatan petani penerima manfaat, peningkatan jumlah petani penerima manfaat dan peningkatan fungsi PUAP sebagai wadah pemecahan masalah kesulitan modal petani. Program Pengembangan Usaha Agribisnis Perdesaan (PUAP) telah menjadi lembaga keuangan yang dimiliki dan dikelolapetani sehingga petani tidak perlu susah untuk mencari modal untuk usahanya dengan syarat yang mudah dan tidak diperlukan jaminan.

Untuk mengetahui lebih jelas mengenai penyaluran BLM-PUAP tersebut dapat dilihat pada tabel di bawah ini:

Tabel. 1 Kelompok Wanita Tani Bina Maju

\begin{tabular}{|c|c|c|c|c|c|c|}
\hline No & Nama Anggota & $\begin{array}{l}\text { Jenis Usaha } \\
\text { Produktif }\end{array}$ & $\begin{array}{c}\text { Kode Usaha } \\
\text { Produktif }\end{array}$ & $\begin{array}{c}\text { Volume } \\
\text { (luas) }\end{array}$ & Nilai (Rp) & $\begin{array}{l}\text { Jadwal Waktu } \\
\text { Pemanfaatan }\end{array}$ \\
\hline 1 & Rahmawati & Cabe & 1.2.b & 0,08 & 4.000 .000 & Mei 2015 \\
\hline 2 & Yusmiati & Cabe & 1.2.b & 0,08 & 4.000 .000 & Mei 2015 \\
\hline 3 & Aprina Harahap & Cabe & 1.2.b & 0,08 & 4.000 .000 & Mei 2015 \\
\hline 4 & Yusriana & Kacang tanah & 1.2.b & 0,08 & 4.000 .000 & Mei 2015 \\
\hline 5 & Mastulen rambe & Kacang tanah & 1.2.b & 0,08 & 4.000 .000 & Mei 2015 \\
\hline 6 & Hefriati harahap & Kacang tanah & 1.2.b & 0,08 & 4.000 .000 & Mei 2015 \\
\hline 7 & Saripah Siregar & Cabe & 1.2.b & 0,08 & 4.000 .000 & Mei 2015 \\
\hline 8 & Nurlela & Cabe & 1.4.b & 0.08 & 4.000 .000 & Mei 2015 \\
\hline & & TOTAL & & $1,04 \mathrm{Ha}$ & \multicolumn{2}{|c|}{ Rp. 32.000 .000} \\
\hline
\end{tabular}

Sumber : Laporan Pengelolaan Pengembangan Usaha Agribisnis Perdesaan (PUAP) Dinas Pertanian Tanaman Pangan dan Hortikultura Kabupaten Tapanuli Selatan

Berdasarkan tabel di atas jelas terlihat bahwa bantuan Pengembangan Usaha Agribisnis Perdesaaan (PUAP) sangan dibutuhkan masyarakat khususnya para petani. Usaha menggerakkan kembali perekonomian masyarakat dalam Program Pengembangan Usaha Agribisnis Perdesaaan (PUAP) dimaksud sebagai suatu upaya meningkatkan kembali segala bentuk kegiatan perekonomian masyarakat skala kecil yang mengalami kelesuan usaha, baik melalui pemberian modal usaha serta pemanfaatan sarana dan prasarana ekonomi baik kepada perorangan, kelompok maupun lembaga perekonomian yang ada.

Pengembangan Usaha Agribisnis Pedesaan (PUAP) adalah bagian dari pelaksanaa program PNPM-Mandiri melalui bantuan modal usaha tani dalam menumbuhkembangkan usaha agribisnis sesuai dengan potensi pertanian desa sasaran, yang dilaksanakan oleh
Departemen Pertanian bertujuan untuk mempercepat tumbuh dan berkembangnya usaha agribisnis dengan sasaran mengurangi kemiskinan dan pengangguran di pedesaan. Sebagaimana hasil wawancara penulis dengan PPL yang menyatakan bahwa: "PUAP adalah merupakan salah satu program yang di kembangkan oleh PNPM Mandiri yaitu berupa bantuan modal usaha tani yang di berikan khusus untuk kelompok tani."

Abadi Siregar juga menyatakan bahwa:" PUAP adalah program dari PNPM mandiri yaitu bantuan modal usaha tani yang diberikan pemerintah khusus untuk kelompok tani di pedesaan."

Masalah paling dasar bagi sebagian besar petani Indonesia adalah masalah keterbatasan modal yang dimiliki oleh para petani. Permasalahan yang dihadapi dalam permodalan pertanian berkaitan langsung dengan kelembagaan selama ini, yaitu lemahnya organisasi tani, 
sistem dan prosedur penyaluran kredit yang rumit, birokratis dan kurang memperhatikan kondisi lingkungan sosial budaya perdesaan, sehingga sulit menyentuh kepentingan petani yang sebenarnya. Dalam rangka menanggulangi permasalahan tersebut, dicanangkan program Pengembangan Usaha Agribisnis Perdesaan (PUAP). Program ini bertujuan untuk membantu mengurangi tingkat kemiskinan dan menciptakan lapangan pekerjaan di perdesaan serta membantu penguatan modal dalam kegiatan usaha di bidang pertanian sehingga dapat meningkatkan kesejahteraan petani. Kehadiran program PUAP diharapkan dapat mengatasi masalah kesulitan modal yang dihadapi petani.

Hal yang sama juga disampaikan oleh Kepala Desa Hanopan bahwa: " PUAP adalah salah satu kegiatan dari program PNPM- Mandiri melalui bantuan modal usaha yang diberikan kepada kelompok tani yang dilaksanakan oleh Departemen Pertanian yang bertujuan untuk mengurangi kemiskinan dan pengangguran di pedesaan."

Pengembangan Usaha Agribisnis Pedesaan dilaksanakan di bawah koordinasi Program Nasional Pemberdayaan Masyarakat Mandiri (PNPM-M) dan berada dalam kelompok pemberdayaan masyarakat. Bentuk kegiatan PUAP adalah fasilitasi bantuan modal usaha agribisnis untuk petani baik petani pemilik, petani penggarap, buruh tani maupun rumah tangga tani.

Selanjutnya Rahmawati juga menyatakan bahwa: "PUAP adalah bantuan modal usaha yang diberikan kepada kelompok tani melalui program PNPMMandiri."

Sesuai dengan wawancara di atas dapat disimpulkan bahwa PUAP menurut pandangan masyarakat adalah salah satu kegiatan dari program PNPM- Mandiri melalui bantuan modal usaha yang diberikan kepada kelompok tani yang dilaksanakan oleh Departemen Pertanian yang bertujuan untuk mengurangi kemiskinan dan pengangguran di pedesaan atau bantuan modal usaha tani yang diberikan pemerintah khusus untuk kelompok tani di pedesaan.

Hal senada juga disampaikan oleh Mardiani bahwa: "PUAP on bantuan nadilehen ni pemerintah khusus tu kelompok tani nadigunahon tu usaha tani." PUAP adalah bantuan yang diberikan oleh pemerintah yang digunakan untuk usaha tani).

Dari hasil wawancara di atas dapat disimpulkan bahwa Program Nasional Pemberdayaan Masyarakat Mandiri Perdesaan (PNPM) adalah program yang dicanangkan oleh Pemerintah Indonesia untuk mempercepat penanggulangan kemiskinan secara terpadu dan berkelanjutan yang dititik beratkan pada pencapaian kesejahteraan dan kemandirian masyarakat miskin perdesaan. Beberapa langkah yang di tempuh dalam mencapai hal tersebut antara lain :

1. Peningkatan kapasitas masyarakat dan kelembagaannya

2. Pelembagaan sistem pembangunan partispatif

3. Pengefektifan fungsi dan peran pemerintahan lokal

4. Peningkatan kualitas dan kuantitas prasarana dan sarana social dasar dan ekonomi masyarakat

5. Pengembangan jaringan kemitraan dalam masyarakat

Pengembangan Usaha Agribisnis Pedesaan (PUAP) merupakan salah satu kegiatan dari Program Nasional Pemberdayaan Masyarakat Mandiri (PNPM-M) yang dilaksanakan oleh Departemen Pertanian, bertujuan untuk mempercepat tumbuh dan berkembangnya usaha agribisnis dengan sasaran mengurangi kemiskinan dan pengangguran di pedesaan. Pelaksanaan PUAP, dirancang dan dilaksanakan oleh masyarakat secara partisifatif dengan membentuk kelompok tani, terintegrasi dengan kegiatan yang telah ada, ataupun yang dilakukan baik dilingkup Departemen Pertanian maupun Non Departemen Pertanian dan Pemerintah Daerah. Pembinaan kelompok tani pada penerapan sistem agribisnis diarahkan untuk meningkatkan peranan petani dan anggota masyarakat lainya dalam 
menumbuhkembangkan kerja sama antar petani dan pihak pemangku kepentingan. Dengan pembinaan kelompok tani diharapkan dapat menggali potensi dalam memecahkan masalah usaha pertanian secara efektif dan memudahkan dalam mengakses informasi pasar, teknologi dan sumber daya lainnya.

Program Pengembangan Usaha Agribisnis Pedesaan (PUAP) sudah menjadi bagian yang tidak terlepas dari binaan seorang PPL sebagai wakil dari Pemerintah dalam meningkatkan pengetahuan dan mengembangkan wawasan petani. PPL membantu petani memperoleh pengetahuan yang khusus berkaitan dengan cara pemecahan masalah yang dihadapi serta akibat yang ditimbulkannya sehingga mereka mempunyai berbagai alternatif tindakan, Selain itu juga dalam meningkatkan motivasi petani untuk dapat menerapkan pilihannya, serta membantu para petani untuk mengevaluasi dan meningkatkan keterampilan mereka dalam membentuk pendapat dan mengambil keputusan.

Sebagaimana dikutip dalam hasil wawancara yang dilakukan penulis mengenai apa saja yang dilakukan oleh PPL tentang program PUAP di Desa Hanopan PPL menyampaikan bahwa:" Yang saya lakukan dalam program PUAP adalah Menumbuhkan kelompok tani, Merencanakan kegiatan kelompok dan, Melaksanakan metode penyuluhan sesuai dengan buku mekanisme dari departemen pertanian dan saya sebagai pembimbing dan guru bagi petani dalam pendidikan non formal, penyuluh memiliki gagasan yang tinggi untuk mengatasi hambatan dalam pembangunan pertanian yang berasal dari petani maupun keluarganya".

Saipul Harahap juga menyampaikan bahwa:"Keberadaan Penyuluh Pertanian Lapangan sangat penting karena mereka berfungsi dalam menumbuhkan kesadaran kelompok tani terhadap kelestarian fungsi lingkungan serta membantu kelompok tani dalam menganalisis dan memecahkan masalah serta merespon peluang dan tantangan dalam mengelola usaha taninya."

Dari sisi kelembagaan kehadiran PUAP juga telah membuat PPL dapat menjadi wadah bagi petani dalam berkumpul dan bermusyawarah memecahkan persoalan yang sedang dihadapi. Kehadiran seorang penyuluh membuat terjadinya ikatan emosional dan dapat terjadi curah pendapat. Dengan demikian pola pikir petani dapat sedikit demi sedikit berubah dan dapat menerima inovasi dalam bidang pertanian.

Hal ini senada dengan yang disampaikan oleh Rahmawati bahwa. "Yang dilakukan PPL dalam program PUAP di Desa Hanopan adalah merencanakan kegiatan kelompok dan melaksanakan penyuluhan tarhadap usaha tani yang sedang kami laksanakan."

Selanjutnya penulis melakukan wawancara tentang apa saja upaya peningkatan ekonomi melalui PUAP, sebagaimana yang disampaikan oleh Rahmawati:" Meningkatkan pola pertanian dari yang tradisional menjadi lebih modern. Hal ini dilihat dari yang biasanya dalam setahun satu kali panen, sekarang sudah dua kali, karena sudah tersedia bibit, pupuk, dan pestisida dari PPL"

Selanjutnya penulis menanyakan kepada PPL :" mengubah pola bertani musim tanam cabe agar panennya direncanakan pada saat menjelang ramadhan dan lebaran."

Pendapat yang sama disampaikan oleh Kepala desa berdasarkan wawancara penulis bahwa:" Diatur musim tanam, pemberian bibit dari PPL, pupuk dan anti hama yang mudah diperoleh karena adanya PPL, serta cara bertani yang sudah lebih maju dengan peralatan yang lebih modern."

Dari hasil wawancara di atas penulis menyimpulkan bahwa upaya peningkatan ekonomi melalui PUAP di Desa Hanopan sudah berhasil dilaksanakan, mulai dari pembibitan, cara tanam, serta pola bertani yang sudah lebih maju.

Agar pengembalian pinjaman dapat berjalan lancar, pengurus dan PPL melakukan suatu fungsi kontrol. Selain kontrol sebelum peminjaman meliputi persyaratan pinjaman, juga dilakukan kontrol pada waktu proses pengembalian pinjaman tersebut. Pengontrolan pada saat pengembalian pinjaman oleh petani 
dilakukan dengan mengadakan pertemuan akhir bulan guna membahas beragam dinamika masalah pertanian di lapangan serta sekaligus mengumpulkan dana angsuran pinjaman oleh petani yang meminjam. Selama waktu penelitian, peneliti melihat belum terjadi penunggakan pengembalian pinjaman. Setiap bulan para petani yang memperoleh pinjaman PUAP menyetorkan uang pinjaman beserta bunga pinjamannya kepada pengurus.

Dari hasil wawancara di atas penulis menyimpulkan keberadaan PPL dalam kelompok tani sebagai wakil dari pemerintah sangat penting dalam hal menyampaikan informasi-informasi tentang program PUAP, Keberhasilan PUAP sangat ditentukan oleh kerjasama dan komitmen seluruh pemangku kepentingan mulai dari tahap persiapan, pelaksanaan sampai dengan dukungan anggaran. Diharapkan dengan adanya pendampingan oleh Penyuluh Pendamping serta adanya pengawalan dan pembinaan yang dapat mendorong tumbuhnya kelembagaan ekonomi petani di perdesaan. Permasalahan mendasar yang dihadapi petani adalah kurangnya akses kepada sumber permodalan, pasar dan teknologi, serta organisasi tani yang masih lemah. Untuk mencapai tujuan PUAP, yaitu mengurangi tingkat kemiskinan dan pengangguran, PUAP difokuskan untuk mempercepat pengembangan usaha ekonomi produktif yang diusahakan para petani di perdesaan.

Pelaksanaan penyuluhan pertanian di era reformasi menggunakan mekanisme kerja yang didasarkan pada pendekatan partisipatif yang memungkinkan petani untuk ikut merencanakan, melaksanakan dan mengevaluasi serta menarik manfaat dari kegiatan penyuluhan pertanian. Hal ini sesuai dengan hasil wawancara yang disampaikan informan bahwa: "Mekanisme pelaksanaan penyuluhan pertanian di Desa Hanopan dilaksanakan melalui jadwal kunjungan PPL sesuai dengan waktu yang ditentukan oleh kelompok tani."

$\begin{array}{llr}\text { Dalam } & \text { hal ini } \begin{array}{r}\text { penulis } \\ \text { menyimpulkan bahwa } \\ \text { penyuluhan pertanian }\end{array} \\ \text { pendekatan mempunyai } & \text { mang memungkinkan petani }\end{array}$

ikut serta merencanakan, melaksanakan dan menarik manfaat dari setiap kegiatan yang dilakukan dalam penyuluhan pertanian serta menentukan sasaran kegiatan PUAP.

Alasan utama penentuan sasaran kegiatan PUAP ini adalah sesuai dengan yang disampaikan ketua kelompok tani bahwa:" Adanya kendala di dalam penyediaan sarana pertanian khususnya adalah pupuk, pestisida, dan alat-alat pertanian dan adanya bentuk dalam penyediaan keperluan pertanian."

Yang dipertegas oleh pernyataan Kepala Desa dalam wawancara penulis berikut: "Adanya kendala dalam penyediaan bahan-bahan yang dibutuhkan petani khususnya pupuk, bibit, pestisida dan alat-alat pertanian. Inilah yang menjadi penentu dari sasaran kegiatan maka untuk itu dibuat kios sarana produksi pertanian dan pengolahan hasil pertanian."

Berdasarkan wawancara yang dilakukan penulis kepada informan mengenai persiapan apa saja yang dibutuhkan dalam pelaksanaan penyuluh pertanian dan program apa saja yang ada dalam penyuluhan, informan menyampaikan bahwa, "Masalah yang dihadapi petugas penyuluhan pertanian dalam menjalankan tugasnya untuk mempersiapkan materi penyuluhan pertanian yaitu : Dana yang sangat kecil, fasilitas yang terbatas, pendidikan yang rendah dan wilayah kerja yang luas. Sedangkan masalah yang dihadapi penyuluh pertanian dilapangan dalam mempersiapkan media penyuluhan pertanian adalah dana yang sangat kecil dan fasilitas yang terbatas. Secara umum usaha-usaha petugas penyuluhan pertanian dilapangan dalam mengatasi masalah dalam persiapan materi dan media penyuluhan pertanian di daerah penelitian hanya sebatas mempergunakan sumberdaya yang ada. Usaha yang lain adalah dengan jalan pembentukan kelompok tani yang berguna dalam efektivitas pengumpulan informasi yang dibutuhkan dalam penyusunan materi penyuluhan pertanian".

Hal ini sesuai dengan kutipan wawancara penulis dengan PPL yang 
menyampaikan bahwa: "Kendala yang dihadapi dalam pelaksanaan penyuluhan pertanian yaitu Sumber Daya Manusia (SDM) petani masih kurang khususnya yang tidak tergabung dalam kelompok tani dan kesadaran dari anggota masyarakat yang basiknya petani untuk ikut kelompok masih kurang serta saluran irigasi di desa yang tidak berfungsi dengan baik yang sering mengakibatkan kekeringan pada musim kemarau dan kebanjiran pada musim penghujan."

Dari hasil wawancara di atas dapat disimpulkan bahwa masih banyak kendalakendala yang di hadapi oleh PPL maupun ketua kelompok tani dalan program PUAP di Desa Hanopan, ditarik kesimpulkan bahwa dengan adanya kebijakan penentuan sasaran PUAP, seluruh lapisan masyarakat dapat memperoleh sarana produksi pertanian dengan jarak yang terjangkau dan harga yang relatif murah. Selain itu, seluruh lapisan masyarakat dapat lebih meningkatkan pengetahuan dalam pengolahan hasil pertanian. Pengolahan hasil pertanian yang baik dapat meningkatkan kualitas produk, memperpanjang daya simpan, dan meningkatkan harga jual produk, sehingga petani dan masyarakat di desa Hanopan dapat meningkatkan hasil pendapatan.

Dalam PNPM Mandiri Perdesaan, seluruh anggota masyarakat didorong untuk terlibat dalam setiap tahapan kegiatan secara partisipatif, mulai dari proses perencanaan, pengambilan keputusan dalam penggunaan dan pengelolaan dana sesuai kebutuhan paling prioritas di desanya, sampai pada pelaksanaan kegiatan dan pelestariannya. Pelaksanaan kegiatan PNPM Mandiri dilakukan oleh masyarakat secara swakelola berdasarkan prinsip otonomi dan difasilitasi oleh perangkat pemerintahan yang dibantu oleh fasilitator atau konsultan.

Tahap pelaksanaan kegiatan dilakukan setelah proses perencanaan selesai dan telah ada keputusan tentang pengalokasian dana kegiatan. Pelaksanaan kegiatan meliputi pemilihan dan penetapan tim pengelola kegiatan, pencairan atau pengajuan dana, pengerahan tenaga kerja, pengadaan barang/jasa, serta pelaksanaan kegiatan yang diusulkan

Untuk itu penulis melakukan wawancara tentang bagaimana pelaksanaan pengawasan PNPM terhadap kegiatan bantuan PUAP, informan menyampaikan: "Dengan cara membentuk Personil tim pengelola kegiatan yang dipilih dan ditetapkan oleh masyarakat, bertanggung jawab dalam realisasi fisik, keuangan, serta administrasi kegiatan/pekerjaan yang dilakukan sesuai rencana. Pada pelaksanaan kegiatan secara swakelola, apabila dibutuhkan barang/jasa berupa bahan, alat, dan tenaga ahli (konsultan) perseorangan yang tidak dapat disediakan atau tidak dapat dilakukan sendiri oleh masyarakat, maka dinas teknis terkait dapat membantu masyarakat untuk menyediakan kebutuhan tersebut. Dan dapat dipertanggung jawabkan".

Hal senada juga disampaikan oleh Saipul Harahap yang menyatakan bahwa:" lya, saya ikut serta dalam proses pengawasan, yaitu dengan membentuk suatu tim yang dapat mempertanggungjawabkan pengalokasian dana serta pelaksanaan kegiatan serta mendata masyarakat yang layak mendapatkan bantuan ini agar bantuan ini tidak salah orang."

Secara umum kehadiran program PUAP telah dapat memberikan dampak positif bagi kesejahteraan petani karena program ini pada dasarnya memberikan bantuan penguatan modal bagi petani. Bantuan modal usaha yang diharapkan dapat meningkatkan pendapatan usaha yang mendukung pendapatan rumah tangga petani sehingga meningkatkan kesejahteraan keluarga.

Kemudian penulis melanjutkan wawancara dengan tentang bagaimana pengaruh tingkat partisipasi PNPM pada keberhasilan program PUAP di Desa Hanopan. Tingkat partisipasi PNPM adalah menciptakan/ meningkatkan kapasitas masyarakat, baik secara individu maupun berkelompok, dalam memecahkan berbagai persoalan terkait upaya peningkatan kualitas hidup, kemandirian dan kesejahteraannya. Abadi Siregar mengatakan : "Pemberdayaan masyarakat 
memerlukan keterlibatan yang besar dari perangkat pemerintah daerah serta berbagai pihak untuk memberikan kesempatan dan menjamin keberlanjutan berbagai hasil yang dicapai. Meningkatnya partisipasi seluruh masyarakat, termasuk masyarakat miskin, kelompok perempuan, komunitas adat terpencil dan kelompok masyarakat lainnya yang rentan dan sering terpinggirkan ke dalam proses pengambilan keputusan dan pengelolaan pembangunan".

Mardiani juga menyampaikan hal yang sama yaitu: "sangat ma huida semangat ni halai nagot mandapot bantuan PUAP I harana tong naloja be marutang tu toke." ( Mereka sangat semangat yang mau mendapatkan bantuan PUAP itu karena tidak lagi berhutang kepada tengkulak).

Berdasarkan hasil wawancara di atas penulis menyimpulkan bahwa partisipasi PNPM dan masyarakat terhadap PUAP sangat berpengaruh, karena dapat menggerakkan kembali perekonomian masyarakat pedesaan dimana PUAP dimaksud suatu upaya meningkatkan kembali segala bentuk kegiatan perekonomian masyarakat skala kecil yang mengalami kelesuan usaha, baik melalui pemberian modal usaha serta pemanfaatan sarana dan prasarana ekonomi.

Sebagaimana hasil wawancara dengan Ibu Rahmawati mengatakan: "Pembentukan kelompok tani dilakukan dalam pertemuan atau dalam musyawarah petani yang dihadiri oleh tokoh masyarakat, pamong desa penyuluh pertanian sebagai mitra kerja petani dan instansi terkait".

Dalam usaha tani membutuhkan biaya yang cukup besar. Keterbatasan dan kesulitan petani dalam memperoleh modal usaha tani, mengakibatkan usaha tani mereka terbengkalai. Rendahnya pengetahuan petani membuat mereka kurang paham bagaimana cara memperoleh kredit atau pinjaman sehingga menyebabkan lemahnya akses petani terhadap lembaga keuangan yang ada. Kelompok tani adalah kumpulan petani/peternak yang dibentuk atas dasar kepentingan dan kebersamaan dalam kondisi lingkungan (sosial, ekonomi, sumberdaya) serta kesepakatan dalam meningkatkan usaha pertanian dari para anggotanya. Jumlah anggota terdiri atas 20-25 orang atau disesuaikan dengan kondisi lingkungan masyarakat, dan usaha ini dipimpin oleh seorang ketua.

Keberadaan kelompok tani berperan sebagai media belajar bagi petani anggota. Melalui kelompok tani ini pula petani dapat mengatasi berbagai persoalan yang dihadapi dalam mengelola usahataninya di lapangan, dibantu dengan bimbingan penyuluh pertanian di lapangan (PPL). Keberadaan kelompok tani erat kaitannya dengan kegiatan penyebarluasan teknologi yang dilakukan penyuluh pertanian. Penyuluhan pertanian pada dasarnya merupakan upaya strategis untuk memberdayakan para petani. Beberapa introduksi teknologi yang dihasilkan, balai penelitian khususnya BP3K, dilakukan melalui kegiatan penyuluhan.

Berdasarkan wawancara dengan Rahmawati tentang bagaimana cara mengelola dana PUAP dalam kelompok tani.: "Cara mengelola dana PUAP yang diberikan kepada anggota kelompok adalah dengan memberikan dana PUAP kepada anggota disesuaikan dengan jadwal peminjaman dan dikembalikan tepat waktu agar dana PUAP tetap bergulir".

Penulis melanjutkan wawancara tentang apa harapan dari pengurus PNPM terhadap PUAP informan menyampaikan bahwa:"Sebagai salah satu pengurus dari PNPM berharap ke depannya PUAP ini tetap berjalan sesuai dengan yang diharapkan oleh masyarakat khususnya yang tergabung dalam kelompok tani agar ekonomi petani semakin meningkat dari tahun ke tahun".

Senada dengan yang diungkapkan oleh Mardiani yang menyatakan bahwa:" Dengan adanya program ini Diharapkan dapat mencapai kesejahteraan dan mendapatkan modal untuk mengembangkan usaha atau budidayanya. Program PUAP ini sangat membantu bagi petani-petani di desa ini, karena dapat dilihat kepedulian pemerintah untuk membuat masyarakat merasakan mendapatkan bantuan yang dapat mensejahterakan dan menambah modal usahanya". 
Hal yang sama juga diungkapkan oleh Saipul Harahap:" Sebagai kepala desa di desa ini berharap dana PUAP tetap berjalan agar perekonomian petani di desa ini semakin membaik".

Dari hasil wawancara di atas ditarik kesimpulan bahwa masyarakat Desa Hanopan sangat berharap agar program pemerintah ini tetap berjalan dari tahun ke tahun agar perekonomian masyarakat petani di Desa Hanopan semakin meningkat.

Berdasarkan pengamatan, para petani yang memperoleh pinjaman sebagian besar memanfaatkan dana tersebut untuk menambah modal usaha taninya. Menurut hasil wawancara, dengan adanya PUAP meningkatkan hasil produksi petani yang tentunya mendatangkan keuntungan, dan pendapatan petani dapat meningkatkan kesejahteraannya. Hal ini juga dapat dilihat dari kehidupan sehari-hari dan tingkat endidikan semakin tinggi.

Untuk itu alangkah baiknya bila program ini dapat diteruskan sebagi salah satu alternatif dalam pemecahan ratusan bahkan ribuan permasalahan kemiskinan yang masih dihadapi petani di seluruh tanah air tercinta. Dan kiranya pelaksanaannya dapat lebih ditingkatkan lagi bukan menjadi semakin mundur karena masih banyak petani yang belum memperoleh PUAP sementara mereka masih-masih memerlukan bantuan dalam meningkatkan peluang agribisnisnya.

\section{SIMPULAN DAN SARAN \\ Kesimpulan}

Berdasarkan uraian di atas yang telah penulis kemukakan pada bab-bab sebelumnya, maka kesimpulan yang didapat dalam upaya peningkatan ekonomi masyarakat melalui Program Pengembangan Usaha Agribisnis Perdesaan (PUAP) di Desa Hanopan Kecamatan Arse Kabupaten Tapanuli Selatan, adalah sebagai berikut :

1. Upaya peningkatan ekonomi masyarakat di Desa Hanopan Kecamatan Arse Kabupaten Tapanuli Selatan adalah dengan bantuan Program Pengembangan Usaha Agribisnis Perdesaan (PUAP), dimana
PUAP dimaksud suatu upaya meningkatkan kembali segala bentuk kegiatan perekonomian masyarakat skala kecil yang mengalami kelesuan usaha, baik melalui pemberian modal usaha serta pemanfaatan sarana dan prasarana ekonomi. Meningkatkan pola pertanian dari yang tradisional menjadi lebih modern. Hal ini dilihat dari yang biasanya dalam setahun satu kali panen, sekarang sudah dua kali, karena sudah tersedia bibit, pupuk, dan pestisida dari PPL, melalui PUAP di Desa Hanopan sudah berhasil dilaksanakan, mulai dari pembibitan, cara tanam, serta pola bertani yang sudah lebih maju.

2. Kehadiran program PUAP telah dapat memberikan dampak positif bagi kesejahteraan petani karena program ini pada dasarnya memberikan bantuan penguatan modal bagi petani. Bantuan modal usaha yang diharapkan dapat meningkatkan pendapatan usaha yang mendukung pendapatan rumah tangga petani sehingga meningkatkan kesejahteraan keluarga.

\section{Saran-saran}

1. Pengelola Program Pengembangan Usaha Agribisnis Perdesaan (PUAP) sebaiknya melakukan pendekatan kepada keluarga-keluarga yang akan mendapatkan bantuan serta melaksanakan pembinaan secara intensif kepada penerima bantuan khususnya keluarga miskin/prasejahtera sehingga bantuan yang diberikan dapat digunakan dan dikembalikan sesuai dengan batas waktu pengembalian. Dalam hal ini diharapkan peran PPL dalam memberikan penyuluhan.

2. Sebaiknya sasaran lokasi benar-benar didata sesuai dengan kriteria penempatan sasaran bantuan, agar bantuan yang diberikan benar-benar tepat pada lokasi sasaran. Disamping itu pengelola Program Pengembangan Usaha Agribisnis Perdesaan (PUAP) harus tegas dalam bertindak sebagai pengurus tanpa adanya perasaan segan dengan orang yang meminta 
tersebut walaupun dia sebagai tokoh masyarakat yang paling disegani, tetapi juga disertai dengan penjelasan yang realistis sehingga tidak membuat orang tersebut menjadi tersinggung atau marah.

3. Bagi masyarakat diharapkan dapat menggunakan dana bantuan Pengembangan Usaha Agribisnis Perdesaan (PUAP) dengan sebaikbaiknya, dan berusaha mengembalikan modal tersebut tepat waktu dan tidak menganggap bantuan dari pemerintah itu cuma-cuma.

\section{DAFTAR PUSTAKA}

Buku:

Abidin, M. Zainal. 2006. Dasar-Dasar IImu Ekonomi. Bogor: Lintas Media.

Adi S. 2001. Kamus Praktis Bahasa Indonesia. Surabaya: Fajar Mulya.

Arikunto, Suharsimi. 2010. Prosedur Penelitian Suatu Pendekatan Praktik, Jakarta: Rineka Cipta.

Mansyur, M. Cholil. 1989. Sosiologi Masyarakat Kota dan Desa. Surabaya: Usaha Nasional.

Muammar. 2006. Ekonomi Islam Indonesia. Jakarta : Arya Duta.

Peraturan Menteri Pertanian No.16/OT.140/2/2008.Jakarta:

Departemen Pertanian RI Tentang Fungsi Kelompok Tani

Poerwodarminta, W.J.S. 2005. Kamus Umum Bahasa Indonesia, Jakarta: Balai Pustaka.

Purwanto, M. Ngalim. 2007. Administrasi Dan Supervisi Pendidikan. Bandung: Remaja Rosdakarya.

Rahardja, Prathama. 2001. Pengantar Ekonomi.Jakarta : PT. Intan Pariwara.

Rosyidi, Suherman. 2004. Pengantar Teori Ekonomi. Jakarta : PT. Raja Grafindo Persada.
Soekanto, Soerjono. 2000. Sosiologi Suatu Pengantar. Jakarta: PT. Raja Grafindo Persada.

Soelaman, M. Munandar. 2000. Ilmu Sosial Dasar, Bandung: PT. Refika Aditama.

Sugiyono. 2010. Metode Penelitian Kuantitatif Kualitatif dan R\&D. Bandung: Alfabeta.

\section{Peraturan:}

Undang-undang Republik Indonesia No 6 Tahun 2014 Tentang Desa 